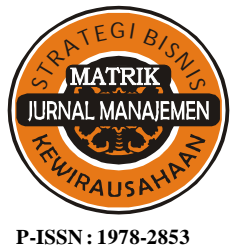

E-ISSN : 2302-8890

\section{MATRIK: JURNAL MANAJEMEN, STRATEGI BISNIS DAN KEWIRAUSAHAAN}

Homepage: https://ojs.unud.ac.id/index.php/jmbk/index

Vol. 14 No. 1, Februari 2020, 56 - 60

\title{
Sikap Etnosentrisme Memoderasi Pengaruh Product Knowledge, Citra Merek dan Gaya Hidup terhadap Keputusan Pembelian Produk UMKM
}

\author{
I Nyoman Nurcaya ${ }^{1)}$, Ni Made Rastini ${ }^{2)}$ \\ ${ }^{1,2}$ Fakultas Ekonomi dan Bisnis Universitas Udayana, Bali \\ email: ichangnur@unud.ac.id
}

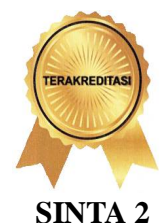

DOI : https://doi.org/10.24843/MATRIK:JMBK.2020.v14.i01.p06

\begin{abstract}
ABSTRAK
Usaha Mikro, Kecil, dan Menengah (UMKM) mempunyai peran penting dalam pembangunan dan pertumbuhan perekonomian Bali. Salah satu UMKM yang tetap eksis dan bertahan di Provinsi Bali adalah UMKM kain endek. Persaingan yang semakin ketat menuntut UMKM endek untuk membuat strategi bersaing yang kompetitif. Penelitian ini bertujuan untuk menjelaskan sikap etnosentrisme konsumen mampu memoderasi product knowledge, citra merek dan gaya hidup terhadap keputusan konsumen untuk membeli produk endek Bali. Untuk mencapai tujuan tersebut digunakan sebanyak 95 orang responden yang tersebar di Propinsi Bali dan akan diambil secara purposive sampling dengan kuisioner sebagai metode pengumpulan datanya. Data diolah dengan alat analisis Partial Least Square (PLS). Hasil analisis menunjukkan bahwa product knowledge, citra merek dan etnosentrisme berpengaruh signifikan terhadap kepusan pembelian kain endek UMKM Bali, sedangkan variabel gaya hidup tidak terbukti signifikan mempengaruhi keputusan pembelian. Variabel etnosentrisme memperkuat pengaruh product knowledge dan citra merek terhadap keputusan pembelian tetapi memperlemah pengaruh gaya hidup terhadap keptusanpembelian.
\end{abstract}

Kata kunci: Etnosentrisme, product knowledge, citra merek, gaya hidup, keputusan pembelian

\section{Ethnosentrism Attitude Moderates The Effect of Product Knowledge, Image Brands and Lifestyle on} Purchase Decisions

\section{ABSTRACT}

The micro, small and medium enterprises (MSMEs) have an important role in the economic growth and development of Bali. One industry of the MSMEs that still exists and survives in the Province of Bali is Endek fabric. The increasing tight competition has forced MSMEs to formulate competitive strategies. This study aims to explain consumer ethnocentrism attitudes in moderating the effect of product knowledge, brand image and lifestyle on consumer decisions to buy endek Bali products. To achieve these objectives 95 respondents spreading across Bali Province were taken using purposive sampling. Data were collected using questionnaires and were. Processed using Partial Least Square (PLS) analysis tools. The results of the analysis show that product knowledge, brand image and ethnocentrism have significant effects on the purchase of Bali SME endek fabric, while lifestyle variables do not prove to significantly influence purchasing decisions. Ethnocentrism variables reinforce the influence of product knowledge and brand image on purchasing decisions but weaken the influence of lifestyle on purchasing decisions.

Keywords: Ethnocentrism, product knowledge, brand image, lifestyle, purchasing decisions

\section{PENDAHULUAN}

Usaha Mikro, Kecil, dan Menengah (UMKM) mempunyai peran penting dalam pembangunan dan pertumbuhan perekonomian Indonesia. Hal ini disebabkan karena UMKM adalah usaha produktif yang berdiri sendiri, yang dilakukan oleh perorangan atau badan usaha disemua sektor ekonomi, sehingga dapat membantu Indonesia dalam perdagangan yang lebih luas. Jumlah UMKM merupakan suatu potensi besar dalam perekonomian. UMKM menjadi sektor segmen bisnis yang vital dalam mendorong pertumbuhan dan kemajuan ekonomi di Indonesia. UMKM dapat berperan dalam meningkatkan lapangan pekerjaan, pembangunan negara, dan penting untuk mendistribusikan hasil pembangunan (Nur et al., 2014). 
Salah satu produk UMKM yang masih bertahan di Propinsi Bali adalah kain endek. Kebutuhan kain endek di Bali semakin meningkat karena tidak hanya digunakan sebagai upacara agama melainkan digunakan untuk aktivitas sehari-hari seperti baju seragam pegawai, anak sekolah maupun dijadikan cendramata yang bernilai ekonomis. Persaingan yang semakin ketat dan akselerasi budaya semakin tinggi khususnya di kalangan generasi muda, menimbulkan kekwatiran terhadap keberlangsungan hidup produk UMKM ini.

Keputusan pembelian konsumen sangat ditentukan oleh tingkat pengetahuan yang dimiliki konsumen mengenai suatu produk, citra merek produk bagi konsumen, serta gaya hidup yang dimiliki konsumen. Gaya hidup yang selanjutnya digunakan dalam penelitian ini adalah gaya hidup traditional. Gaya hidup traditional adalah kelompok individu yang memegang norma-norma keluarga dan masyarakat. Mereka umumnya lambat menerima produk baru dan lambat dalam meniru gaya hidup. Gaya hidup tradisional cendrung fanatik dengan produk UMKM atau produk lokal. Dari latar belakang tersebut peneliti ingin mengkaji apakah sikap etnosentris masyarakat Bali memoderasi variabel perilaku konsumen dalam keputusannya membeli kain endek sebagai produk UMKM Bali.

Menurut Kotler dan Keller (2012 : 166), proses keputusan pembelian terdiri dari limatahap yang dilakukan oleh seorang konsumen sebelum sampai pada keputusan pembelian dan selanjutnya pasca pembelian. Keputusan pembelian yang dilakukan oleh konsumen dapat terjadi apabila kosumen sudah mendapatkan pelayanan dari pemberian jasa dan setelah itu konsumen merasakanadanyakepuasan dan ketidakpuasan, maka dari itu konsep- konsep keputusan pembelian tidak lepas dari konsep kepuasan pelanggan. Secara umum manusia bertindak rasional dan mempertimbangkan segala jenis informasi yang tersedia dan mempertimbangkan segala sesuatu yang mungkin bisa muncul daritindakannya sebelum melakukan sebuah perilaku tertentu.

Menurut Nan-Hong Lin (2007) "Product knowledge is a perception consumers have towards certain product, including previous experience of using the product" artinya: Pengetahuan produk adalah konsumen memiliki persepsi terhadap produk tertentu, termasuk pengalaman sebelumnya menggunakan produk.

Menurut Lin \& Lin (2007:122) mengukur pengetahuan produk dengan tiga cara, yaitu (1)
Subjective knowledge, merupakan tingkat pengertian konsumen terhadap suatu produk,sering disebut menilai pengetahuan sendiri (self- assessed knowledge), (2) Objective knowledge, yaitu: tingkat dan jenis pengetahuan produk yang benarbenar tersimpan dalam memori konsumen, disebut juga pengetahuan actual (actual knowledge). (3) Experience-based knowledge, merupakan pengalaman sebelumnya dari pembelian atau penggunaan produk.

Menurut Tjiptono (2005: 49), brand image atau brand description, yakni deskripsi tentang asosiasi dan keyakinan terhadap merek tertentu. Citra merek dapat dianggap sebagai jenis asosiasi yang muncul dalam benak konsumen ketika mengingat suatu merek tertentu. Asosiasi itu dapat muncul dalam bentuk citra atau pemikiran tertentu yang dikaitkan dengan suatu merek.

Citra merek berhubungan dengan sikap. Sikap positif konsumen terhadap sebuah merek lebih mudah mengarahkannya untuk membeli merek dan produk tersebut. Karena itu, tujuan utama strategi pemasaran, baik melalui iklan, publisitas maupun melalui cara tradisional adalah mengembangkan citra positif terhadap merek. Citra merek dibangun dengan memasukkan kepribadian atau citra kedalam produk atau jasa, untuk kemudian dimasukkan ke dalam alam bawah sadar konsumen.

Gaya hidup menurut Kotler (2002) adalah pola hidup seseorang di dunia yang diekspresikan dalam aktivitas, minat, dan opininya, dalam arti bahwa secara umum gaya hidup seseorang dapat dilihat dari aktivitas rutin yang dilakukan, apa yang mereka pikirkan terhadap segala hal disekitarnya dan seberapa jauh dia peduli dengan hal itu dan juga apa yang dia pikirkan tentang dirinya sendiri dan juga dunia luar. Setiap individu memiliki gaya hidup yang berbeda, yang kemudian mempengaruhi budaya konsumsi dan juga barang yang biasa dikonsumsi, hal ini dapat dimanfaatkan oleh para pemasar untuk bisa meningkatkan efisiensi dan efektivitas pemasaran mereka. Pada dasarnya, manusia sudah terbiasa hidup berkelompok sesuai dengan kelas ekonomi dan gaya hidupnya sehingga hal ini akan membedakan kebutuhan dan keinginannya.

Taylor, Peplau dan Sears (2000) menyatakan bahwa etnosentrisme mengacu pada suatu kepercayaan bahwa in group nya lebih baik atau superior dari pada out group.Secara ringkas pengertian etnosentrisme adalah kecenderungan untuk memandang norma-norma dan nilai dalam kelompok budayanya sebagai yang terbaik dan 
digunakan sebagai standar untuk mengukur dan bertindak terhadap semua kebudayaan lain. Etnosentrisme ini melibatkan atribusi internal dan eksternal yang menciptakan jurang pemisah dengan kebudayaan lain, sehingga tidak memungkinkan terjadinya komunikasi dan kontak sosial yang harmonis.

Shimp dan Sharma (dalam Bamber et al, 2011) menemukan bahwa konsumen dengan etnosentrisme yang lebih tinggi mengevaluasi produk impor yang berdampak pada perekonomian. Konsumen percaya membeli produk impor yang tidak patriotik karena mengakibatkan hilangnya pekerjaan domestik dan menyebabkan kerusakan pada perekonomian domestik. Sedangkan konsumen yang memiliki etnosentrisme rendah cenderung mengevaluasi produk impor menggunakan atribut produk daripada country of origin produk

Berdasarkan teori dan kajian sebelumnya, maka UMKM kain endek dapat membuat strategi yang bersifat kompetitif untuk memenangkan persaingan dengan memperhatikan faktor-faktor yang mempengaruhi keputusan pembelian seperti Product Knowledge, Cira Merek, Gaya Hidup, dan peran sifat etnosentrisme dari para pelanggan.

\section{METODE PENELITIAN}

Penelitianini bersifat asosiatif yaitu bertujuan menjelaskan peran variable Sikap Etnosentrisme dalam memoderasi pengaruh variabel Product
Knowledge, Citra Merek, dan Gaya hidup terhadap Keputusan Pembelian produk UMKMyang dalam hal ini adalah kain endek Bali.

Populasi penelitian ini adalah seluruh masyarakat Bali yang pernah membeli kain endek. Jumlah sampel yang digunakan dalam penelitian ini yaitu 95 orang responden karena sudah memenuhi syarat untuk dapat digunakan sebagai model estimasi. Teknik sampling yang dipakai adalah Purposive Sampling, yaitu teknik pengambilan sampel dengan kriteria tertentu. Kriteria yang dimaksud adalah sudah mengenal kain Endek Bali berpendidikan serendahrendahnya SMA sederajat.

Teknik Analisis data dalam penelitian ini menggunakan pendekatan Partial Least Square (PLS). PLS adalah model persamaan Structural Equation Modelling (SEM) yang berbasis komponen atau varian. Analisis PLS hampir sama dengan Analisis Regresi namun lebih dari itu, secara simultan menggabungkan hubungan antar variabel laten dan sekaligus mengukur hubungan antara variabel laten dengan indikatornya.

\section{HASIL DAN PEMBAHASAN}

Pengujian hipotesis tentang pengaruh Product Knowledge, Citra Merek, Gaya Hidup, Etnosentrisme, dan interaksi antara ketiga variabel bebas sebelumnya dengan Etnosentrisme terhadap Keputusan Pembelian disajikan pada Tabel 1.

Tabel 1 Hasil Estimasi dan $P$ Value

\begin{tabular}{|c|c|c|c|c|c|}
\hline Hubungan & $\begin{array}{l}\text { Original } \\
\text { Sampel }\end{array}$ & $\begin{array}{l}\text { Sample } \\
\text { Mean }\end{array}$ & $\begin{array}{c}\text { Standar } \\
\text { Deviation }\end{array}$ & $\begin{array}{c}T- \\
\text { Statistic } \\
\end{array}$ & $\begin{array}{c}P \\
\text { Value } \\
\end{array}$ \\
\hline Citra Merek -> Keputusan Pembelian & 0,391 & 0,381 & 0,116 & 3,373 & 0,001 \\
\hline $\begin{array}{l}\text { Citra Merek x Etnosentrisme -> Keputusan } \\
\text { Pembelian }\end{array}$ & 0,278 & 0,259 & 0,115 & 2,404 & 0,017 \\
\hline Etnosentrisme -> Keputusan Pembelian & 0,257 & 0,259 & 0,112 & 2,282 & $0,02=$ \\
\hline Gaya Hidup -> Keputusan Pembelian & $-0,105$ & $-0,103$ & 0,148 & 0,712 & 0,477 \\
\hline $\begin{array}{l}\text { Gaya hidup x Etnosentrisme -> Keputusan } \\
\text { Pembelian }\end{array}$ & $-0,386$ & $-0,336$ & 0,151 & 2,549 & 0,011 \\
\hline $\begin{array}{l}\text { Product Knowledge x Etnosentrisme }-> \\
\text { Keputusan Pembelian }\end{array}$ & 0,236 & 0,201 & 0,108 & 2,192 & 0,025 \\
\hline $\begin{array}{l}\text { Product Knowledge -> Keputusan } \\
\text { Pembelian }\end{array}$ & 0,458 & 0,467 & 0,123 & 3,730 & 0,000 \\
\hline
\end{tabular}

Sumber: Data diolah,

Hasil pengujian hipotesis pertama menunjukkan bahwa product knowledge berpengaruh positif signifikan terhadap keputusan pembelian. Hal ini ditunjukkan oleh nilai koefisien estimasi sebesar 0,458 dengan nilai $P$ value sebesar 0.000 . Semakin baik pengetahuan seseorang terhadap sebuah produk maka keputusan pembelian juga akan semakin tinggi. Hasil pengujian hipotesis ini menunjukkan bahwa Hipotesis 1 diterima.
Hasil pengujian hipotesis kedua menunjukkan bahwa citra merek berpengaruh positif signifikan terhadap keputusan pembelian. Hal ini ditunjukkan oleh nilai koefisien estimasi sebesar 0,391 dengan nilai $P$ value sebesar 0.001 . Semakin tinggi citra merek maka keputusan pembelian juga akan semakin tinggi. Hasil pengujian hipotesis ini menunjukkan bahwa Hipotesis 2 diterima. 
Hasil pengujian hipotesis ketiga menunjukkan bahwa gaya hidup tidak secara signifikan berpengaruh negatif terhadap keputusan pembelian. Hal ini ditunjukkan oleh nilai koefisien estimasi sebesar -0,105 dengan nilai $P$ value sebesar 0.477. Gaya hidup yang semakin tinggi bukan jaminan bahwa keputusan pembelian akan semakin tinggi pula. Hasil pengujian hipotesis ini menunjukkan bahwa Hipotesis 3 ditolak.

Hasil pengujian hipotesis keempat menunjukkan bahwa etnosentrisme berpengaruh positif signifikan terhadap keputusan pembelian. Hal ini ditunjukkan oleh nilai koefisien estimasi sebesar 0,257 dengan nilai $P$ value sebesar 0.023 . Semakin kuat etnosentrisme maka keputusan pembelian juga akan semakin tinggi. Hasil pengujian hipotesis ini menunjukkan bahwa Hipotesis 4 diterima.

Hasil pengujian hipotesis kelima menunjukkan bahwa etnosentrisme mampu memoderasi secara positif pengaruh product knowledge terhadap keputusan pembelian. Hal ini ditunjukkan oleh nilai koefisien estimasi sebesar 0,236 dengan nilai $P$ value sebesar 0.029. Semakin tinggi pengetahuan seseorang tentang produk dan didukung oleh etnosentrisme yang semkin tinggi maka keputusan pembelian juga akan semakin tinggi. Hasil pengujian hipotesis ini menunjukkan bahwa Hipotesis 5 diterima.

Hasil pengujian hipotesis keenam menunjukkan bahwa etnosentrisme mampu memoderasi secara positif pengaruh Citra merek terhadap keputusan pembelian. Hal ini ditunjukkan oleh nilai koefisien estimasi sebesar 0,278 dengan nilai $P$ value sebesar 0.017 . Semakin tinggi citra merek suatu produk dan didukung oleh etnosentrisme yang semkin tinggi maka keputusan pembelian juga akan semakin tinggi. Hasil pengujian hipotesis ini menunjukkan bahwa Hipotesis 6 diterima.

Hasil pengujian hipotesis ketujuh menunjukkan bahwa etnosentrisme mampu memoderasi secara negatif pengaruh Gaya hidup terhadap keputusan pembelian. Hal ini ditunjukkan oleh nilai koefisien estimasi sebesar $-0,386$ dengan nilai $P$ value sebesar 0.011. Semakin tinggi gaya hidup seseorang dan didukung oleh etnosentrisme yang semkin tinggi maka keputusan pembelian juga akan semakin rendah. Hasil pengujian hipotesis ini menunjukkan bahwa Hipotesis 7 diterima.

\section{KESIMPULAN DAN SARAN}

Berdasarkan kajian teori, analisis data dan pembahasan, maka dapat disimpulkan bahwa Product knowledge berpengaruh positif signifikan terhadap keputusan pembelian kain endek di Provinsi Bali. Citra merek berpengaruh positif signifikan terhadap keputusan pembelian kain endek di Provinsi Bali. Gaya hidup tidak berpengaruh signifikan terhadap keputusan pembelian kain endek di Provinsi Bali. Sikap etnosentrisme berpengaruh positif signifikan terhadap keputusan pembelian kain endek di Provinsi Bali. Sikap entosentrisme secara signifikan memoderasi (memperkuat) pengaruh product knowledge terhadap keputusan pembelian kain endek di Provinsi Bali. Sikap entosentrisme secara signifikan memoderasi (memperkuat) pengaruh Citra merek terhadap keputusan pembelian kain endek di Provinsi Bali. Sikap entosentrisme secara signifikan memoderasi (memperlemah) pengaruh Gaya hidupterhadap keputusan pembelian kain endek di Provinsi Bali

Para produsen kain endek di Provinsi Bali dan di fasilitasi oleh Pemerintah Provinsi Bali hendaknya melakukan promosi yang bersifat edukasi bahwa kain endek Bali memiliki kualitas bagus dan disain yang menarik. Pemerintah membantu dalam membuat kebijakan yang menekankan pentingnya kita menghargai produk-produk dalam negeri, seperti membuat pakaian seragam dari kain endek.

\section{REFERENSI}

Bamber et al. (2011). Product-Knowledge, Ethnocentrism and Purchase Intention: COO Study in India. Working Paper No. 112/ 2011.

De Mooij, Marieke. (2004). Consumer Behavior and Culture: Consequences for Global Marketing and Advertising. Thousand Oaks, CA; Sage Publications.

Diatmika Eka Pratama, I. G. B. A. C., Kerti Yasa, N. N., \& Nurcaya, N. (2017). The Role of Brand Image in Mediating the Influence of Sponsorship on the Intention to Purchase. International Journal of Management and Commerce Innovations, 5(2), 997-1003. https:/ /doi.org/10.15713/ins.mmj.3

Dodds, W. B., Monroe, K. B., \& Grewal, D. (1991). Effects of Price, Brand, and Store Information on Buyers' Product Evaluations. Journal of Marketing Research, 28(3), 307. https:// doi.org/10.2307/3172866

Fadila, Dewi dan Rasyid Nirwan. (2012). Pengaruh Ethnosentrisme Konsumen Terhadap Keterlibatan Pengambilan Keputusan Pembelian Produk. Jurnal Orasi Bisnis Edisi ke-VII, Mei 2012.

Fakharmanesh, S., \& Miyandehi, R. G. (2013). The Purchase of Foreign Products: The Role of 
Brand Image, Ethnocentrism and Animosity: Iran Market Evidence. Iranian Journal of Management Studies (IJMS) Iranian Journal of Management Studies, 6(1), 147-162.

Fernández-Ferrín, P., Bande-Vilela, B., Klein, J. G., \& Luisa Del Río-Araújo, M. (2015). Consumer ethnocentrism and consumer animosity: Antecedents and consequences. International Journal of Emerging Markets, 10(1), 73-88. https://doi.org/10.1108/IJOEM-11-2011-0102

Ghozali, I. (2008). Structural Equation Modeling: Metode Alternatif Dengan Partial Least Square. Semarang: BP. Univerisitas Diponegoro.

Josiassen, A., Assaf, A. G., \& Karpen, I. O. (2011). Consumer ethnocentrism and willingness to buy: Analyzing the role of three demographic consumer characteristics. International Marketing Review, 28(6), 627-646. https:// doi.org/10.1108/02651331111181448

Pradesta, R. B. (2014). Pengaruh Etnosentrisme, Brand Image Dan Product Knowledge Terhadap Keputusan Pembelian Produk Pakaian Jadi Impor. Fakultas Ekonomi Manajemen Universitas Muhammadiyah Surakarta.

Qing, P., Lobo, A., \& Chongguang, L. (2011). The impact of lifestyle and ethnocentrism on consumers' purchase intentions of fresh fruit in Chinanull. Journal of Consumer Marketing, 29(1), 43-51. https://doi.org/ $10.1108 / 07363761211193037$

Schiffman, LG dan Kanuk, LL. (2000). Consumer Behavior. Prentice-Hall, Inc. New Jersey; Upper Saddle River.
Sharma, S., Shimp, T.A. and Shin, J. (1995), Consumer ethnocentrism: a test of antecedents and moderators, Journal of the Academy of Marketing Science, Vol. 23, No. 1, pp. 26-37.

Suryadi, Nanang dan Hendrawan Dimas. (2010). Kecenderungan Etnosentrisme, Sikap dan Intensi Konsumen dalam Membeli Produk Sepatu UKM. Jurnal Aplikasi Manajemen. Volume 8 No. 2.

Wahyuni, N. L. G., \& Suparna, G. (2014). Pengaruh Brand Image dan Product Knowledge Terhadap Purchase Intention Produk Tas Tiruan di Kota Denpasar. E-Jurnal Manajemen Universitas Udayana, 3(4), 1022-1034. Retrieved from https://ojs.unud.ac.id/index.php/Manajemen/ article/view/7540

Wang CL, Chen ZX. (2004). Consumer Ethnocentrism and Willingness to Buy Domestic Products in Developing Country Setting Testing Moderating Effects. Journal of Consumer Marketing. Volume 21 No. 6. Page 391-400

Wirawan, N. (2016). Cara Mudah Memahami Statistika Ekonomi dan Bisnis (Statistika Deskriptif) (Keempat). Denpasar: Keraras Emas.

Wu, Jianlin, Zhu Ning, Dai Qi. (2010). Consumer Ethnocentrism, Produc Attitudes and Purchase Intentions of Domestic Product in China. Scientific Research. International Conference on Engineering and Business Management (EBM 2010). 